low limit to which the water recedes during the montluly spring-tides. In no case less than thirty, and not unfre. quently mo e than forty feet represents the vertical height of the rise and fall of the tide on these occasions, the waves on "their retreat exposing to view and rendering accessible an extent of rocks and life-teeming pools that constitute a veritable elysium to the marine zoologist or botanist. The situation of Jersey, again, is such as to render it not only readily accessible to English naturalists and students, accompanied with just that amount of seapassage requisite to satisfy the marine predilections of our countrymen, but it is also most conveniently reached from France, Belgium, Holland, and other Northern European countries, and which will thus invest the institution with international utility. Paris, indeed, already supplies a considerable number of the numerous summer visitors to the island, and from these no doubt might be enticed a strong contingent of students for the laboratories.

As will be found in the advertisement already referred to, a special appeal is addressed to the scientific section of the community ratber than to the general public for the funds required for the successful establishment of this institution, and it is certainly most desirable that an enterprise calculated hereafter to confer so great advantages upon this more limited class should receive a fair quota of support through its ranks. The sum total required, in fact-5,000\%-for the founding of this zoological station, and all accessory departments, is so comparatively small as to place it not quite beyond the pale of hope that sufficient enthusiasm to effect the purpose may be yet forthcoming from among the more wealthy devotees to the shrine of science, and in emulation of the praiseworthy example set on the other side of the Atlantic by Mr. John Anderson, the munificent founder and endower of the Penikese Island Station. At all events, it is scarcely to be anticipated that so desirable an undertaking, replete with such promise of future advantage to the scientific world, will long lack the essential "sinews of war," considering that a contribution by each member of one only of our leading metropolitan. scientific societies of less than one-half of his annual subscription to that society, would more than suffice to defray the whole expenditure contemplated. Through the kind liberality of a few, moreover, and the financial confidence of others, a small but substantial nucleus has been already formed, and it is confidently hoped that the full sum needed may yet be raised in time for naturalists and the public generally to participate in the advantages the Channel Islands' Zoological Station and Museum of Pisciculture will place at their disposal, so early as the summer of the year 1878 .

In conclusion it is perhaps desirable to note that in drawing up the legal foundation of this Channel Islands' institution the strictest care has been taken to permanently exclude all possible chance of the society's premises being used for any of those attractions of an entirely irrelevant and unscientific nature more usually associated with exhibitions of the living inhabitants of the ocean, and the existence of which must ever constitute an insuperable barrier to that good service to science which these lastnamed establishments might otherwise contribute. It is only under such restrictions as are above set forth that patronage and support are solicited. In recognition of the purely scientific status of this enterprise, the members of the Executive Committee, or Directors of the Society, have also unanimously resolved to accord their services as such members gratuitously; and it is further pro posed, so as to divest the undertaking of any merely speculative aspect, that all profits arising from the business of the society, beyond what would yield to the shareholders a return of five per cent., shall be devoted to the further development of the institution, or otherwise towards the aid and promotion of scientific research.

St. Helier's, Jersey

W. SAVILLE KENT

\section{GERMAN UNIVERSITIES}

THERE have been comparisons made recently both in this and in other journals between the Universities of Germany and those of this country, and as the university question is at present giving rise to much discussion, it may be useful to give some statistics with reference to the former. Such statistics are much more easily attainable for Germany than for England, as there are two German publications in which all the important information concerning the various universities of the empire is systematically arranged, viz., the Deutsche Universitäts Kalendar and the Deutsche akcademisches fahrbuch. To obtain similar information concerning the universities of the United Kingdom it would be necessary to obtain a copy of the calendar of each university. Our statistics are obtained from the fahrbuch, which contains information not only relating to the universities, but also to the technical and high schools, learned societies, and libraries of the country. Some such publication is wanted here, and might be made to include not only our various universities and colleges, but also our principal public schools. The fahrbuch includes, moreover, the Russo-German University of Dorpat, the Universities of Vienna, Graz, Innsbruck, Prague, Czernowitz, Basel, but these we shall not take into account.

Germany has in all twenty-one universities, each complete in all departments. The number of students matriculated and non-matriculated attending each, mostly in the I $876-77$ semester was as follows :-

\begin{tabular}{|c|c|c|c|c|c|c|c|c|}
\hline & & & & tricula & d Stude. & & ت्छ & \\
\hline & & & 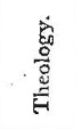 & 密 & 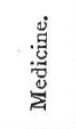 & 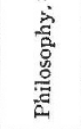 & 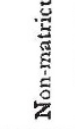 & Total. \\
\hline Berlin ... & $\ldots$ & $\ldots$ & 139 & 1003 & $28 r$ & 1067 & 2107 & 4597 \\
\hline Bonn $\ldots$ & $\ldots$ & $\ldots$ & 163 & 200 & II 8 & 312 & 36 & 829 \\
\hline Breslau & $\ldots$ & $\ldots$ & 107 & 377 & 165 & $45^{8}$ & 15 & r122 \\
\hline Erlangen & $\ldots$ & $\ldots$ & I36 & 37 & IO2 2 & I 47 & & 422 \\
\hline Freiburg & $\ldots$ & $\cdots$ & $4 I$ & 64 & 128 & 60 & 36 & 329 \\
\hline Giessen"2 & $\ldots$ & $\ldots$ & - & - & - & - & ro & $33 \mathrm{I}$ \\
\hline Gö:tingen & $\ldots$ & $\ldots$ & $7 \mathrm{I}$ & 324 & 122 & 474 & - & 991 \\
\hline Greifswald & $\ldots$ & $\ldots$ & 32 & 89 & 235 & 142 & 9 & 507 \\
\hline Halle ... & $\ldots$ & $\ldots$ & 190 & $15^{\circ}$ & 103 & 439 & I 6 & 898 \\
\hline Heidelberg & $\ldots$ & $\ldots$ & 9 & 410 & IOI & 215 & 60 & 795 \\
\hline Jena $\ldots$ & $\ldots$ & $\ldots$ & 66 & IOI & $7 \mathrm{I}$ & 201 & 20 & 459 \\
\hline Kiel $\quad \ldots$ & $\ldots$ & $\ldots$ & 47 & 14 & 73 & 78 & II & 223 \\
\hline Köaigsberg & $\ldots$ & $\ldots$ & 44 & 186 & 127 & 264 & 10 & $63 \mathrm{I}$ \\
\hline Leipzig & $\ldots$ & $\ldots$ & 328 & YIO2 & 364 & II 82 & $\mathrm{II}_{3}$ & 3089 \\
\hline Marburg & $\ldots$ & $\ldots$ & 49 & 65 & 104 & 164 & 4 & 386 \\
\hline Mun:ch & $\ldots$ & $\ldots$ & 75 & 357 & $440^{3}$ & $408^{4}$ & $\ldots$ & I280 \\
\hline Münster & $\ldots$ & $\ldots$ & 208 & - & - & 223 & - & $43 \mathrm{I}$ \\
\hline Rostock & $\ldots$ & $\ldots$ & 24 & 35 & 31 & 54 & - & 144 \\
\hline Sirassburg & $\ldots$ & $\ldots$ & 49 & $2 \mathrm{II}$ & I 78 & $236^{5}$ & 26 & 700 \\
\hline Tüibingen & $\ldots$ & $\ldots$ & 295 & $25 \mathrm{r}$ & 138 & $335^{6}$ & 6 & 1025 \\
\hline Wuirzburg & $\ldots$ & $\ldots$ & 150 & 93 & 547 & 328 & 22 & 1040 \\
\hline & & & 2223 & 5069 & 3428 & 6787 & 2501 & 20229 \\
\hline
\end{tabular}

Thus, then, there are about I8,000 matriculated students attending the twenty-one universities of Germany, under a teaching staff of about I,300 paid professors, besides about $45^{\circ}$ privat-docenten. Of the students, about one-third belong to the philosophical faculty, the faculty in which the sciences are included. Unfortu-

"In "Philosophy" are included the physical and natural sciences.

2 The Giessen students are divided into Hessian and non-Hessian, noi according io faculties.

3 Including roo students of pharmacy.

4 Including 9 siudents of forestry.

5 Including 97 mathematical and natural science students, these being a, separate far,uity at Strassburg. The figures are for $1875 \cdot 6$.

lncluding 53 studeats in political economy aud $x 41$ in natural scienco these subjects forming separate faculties at Tübingen, 
nately, in very few cases is the number of students attending the scientific as distinct from the literary classes given, and only in one or two universities has science as yet been erected into a separate faculty. If we may take the two universities, Strassburg and Tübingen, in which natural science forms a separate faculty as a criterion from which to judge of the number of students of science in the other universities, the proportion must be very large. In Strassburg, of the 236 students whom we have placed in the philosophical faculty, ninety-seven are students of science, and in Tübingen Ioo, or something like one-third of the whole philosophical faculty. Or again, if the number of science students is at all in proportion to the number of science teachers, the position held by science in German universities is in striking contrast to its fos tion in our universities and colleges. Of the professors, among whom we do not count the privat-docenten, about one-half belong to the philosophical faculty, and of these again, nearly one-half are teachers of science, that is, in the philosophical faculty of the German universities there is one teacher on an average to every ten students, and in science the proportion is considerably greater. In these estimates we do not take account of the medical faculty, in which, in most of the universities, there are several chairs which might well be classed as belonging to science generally.

For example, the well-known anthropologist, Dr. Virchow, the conclusion of whose address at the German Association we give this week, is Professor of Pathology at Berlin, and has been able to bring the results of his special medical line of investigation to bear, in an important way, upon his anthropological researches. Both in Berlin and elsewhere, other names of eminent medical professors might be mentioned who have not only themselves made important contributions to science, but under whom students are encouraged to do so likewise.

Of the nature and extent of the scientific teaching in German universities some idea may be formed from the subjects represented by the teaching staff at Berlin, which may fairly be taken as a type of the whole. In Berlin then we find that there are (excluding the privat-docenten) five professors of mathematics, two of astronomy, seven of chemistry, five of physics, three of geology, four of botany, two of zoology, one of meteorology, two of geography, one of anthropology, and one of agriculturephysiology and comparative anatomy being well represented in the medical faculty, and we might well have included among teachers of science those who devote themselves to the scientific investigation of languages. But a mere statement of the number of teachers gives no adequate idea of the means at the command of a German University for training its students in science. The number of teachers in each subject secures that its various departments will be thoroughly worked out, and gives a student a chance of following out any specialty he may take up; this is made still further possible by the number and variety of institutions, museums, laboratories, collections, \&c., attached to each university, not to speak of its large and comprehensive library. In connection with Berlin alone there are twentythree scientific " Anstalten," as they are called, for practical investigation in connection with the various faculties. Had we taken the numerous Realschule and the high and polytechnic schools into account, where an education can be obtained quite equal to that obtainable at most of our universities and colleges, it would have been seen that higher education in Germany leaves little to be desired.

And in reference to the subject of our leader this week, we would point to these Realschulen as embodying the German idra of what practical training should be. The carefully drawn-up time-tables of these schools are an instructive study, showing, as they do, that general menta? culture is regarded as of the first importance in training a youth for the work of the world.
The $7 a h r b u c h$ gives a statement of income and expenditure in connection with only one or two of the universities. Some interesting details, however, on the contributions of the State to the universities, as well as on other points, were given in a recent number of the Academy by Prof. Ray Lankester :-

"The sum expended by the North German States on the twenty universities belonging to them is annually more than 500,000l. The Imperial Government has expended upon the new University of Strassburg alone $70,000 \%$. in one year. The University of Leipzig alone receives annually from the Saxon Government over 50,000 . There are eight universities in North Germany which are little, if at all, less costly, and there are eleven of smaller size which receive each from $8,000 l$. to $20,000 \%$. annually.

"In North Germany there is one university to every two million inhabitants; in Austria there is one to every five millions; in Switzerland one for each million; in England one to every seven millions. In the twenty North German universities there are $x, 250$ professors.? In the British Islands we ought to have sixteen universities and $I, 000$ professorships in order to come up to the same level in this respect as North Germany. The stipend (apart from fees) of a professor in a German university ranges from $100 \%$, to $600 l$. a year. As a rule, at the age of five and-thirty, a man in this career may (in Germany) count on an assured income of $400 l$. a year (with retiring pension). The expenditure on attendants, libraries, laboratories, and officials may be calculated as being (in a well-conducted university) more than equal in amount to the total of the professors' stipends. Taking the average German professorial stipend at only $200 l$. a year, we find that $250,000 l$. must be spent annually on this item alone in the North German States.

"In order to equip and carry on sixteen universities in this country which should bear comparison with the German universities, we require not less than an immediate expenditure of $1,000,000 l$. sterling in building and apparatus, and an annual expenditure of from $500,000 l$. to $800,000 l . "$

When we add to the Government subsidy the income of the universities from other sources, the sum is enormously increased. The half-million, moreover, does not include the occasional grants of the Government for special purposes. Some idea of the magnificence of these was shown in our recent "University Intelligence," where it was stated that in the budget submitted to the present Prussian House of Deputies are the following items :-Erection of the German Industrial Museum, 998,000 mk.; erection of a Polytechnic in Berlin, 8,393,370 mk.; erection of an Ethnological Museum in Berlin, I,800,000 mk. ; and for the Berlin University, erection of an Herbarium, 422,000 $\mathrm{mk}$. ; of a Clinic, I, 955,000 mk. ; of a new building for a second Chemical Laboratory, as well as of a Technical and Pharmaceutical Institute, 967,000 mk.

\section{OUR ASTRONOMICAL COLUMN}

THE METEORI'E OF JULY 20, I86o.-The occurrence of the splendid meteor of November 23, which has probably been observed with sufficient completeness to allow of the determination of its path, while it remained visible, recalls a similar object which passed over the northern parts of the United States and adjacent parts of Canada, on the evening of July 20,1860 , which was made the subject of investigation by the late Prof. J. H. Coffin, of Lafayette College, N.Y. Probably no one of these remarkable bodies has been more extensively observed, and we do not remember any case where the calculations have been more laboriously conducted, and with greater hope of reliable results.

*i.e. we presume professors strictly so-called, exclusive of "privat 